\title{
CORRIGENDUM
}

Genes \& Development 34: 663-677 (2020)

\section{Corrigendum: Developmental regulation of cell type-specific transcription by novel promoter-proximal sequence elements}

Dan Lu, Ho-Su Sin, Chenggang Lu, and Margaret T. Fuller

In the above-mentioned article, it has come to the authors' attention that the CNAAATT motif was originally discovered in the 5'UTR of the Mst87F gene as the translational control element (TCE) (Schäfer et al. 1990) and was later found to be prevalent among many testis-specific genes (Katzenberger et al. 2012). In these published works, the motif was shown to be important for testis-specific expression of these genes through careful experimental and computational analysis. The current article has been updated to add both citations to the following paragraph on p. 670 and to the References.

"MEME-ChIP analysis of the promoter regions from the off-to-on genes identified a second downstream motif, CNAAATT $\left(E\right.$-value $=6.9 \times 10^{71}$ from DREME) (Fig. 6A, right column), most enriched in the off-to-on genes between +29 and +60 bp downstream from the dominant TSS (Fig. 6B, right panel). This motif was very similar to what was identified previously as the translational control element (TCE) that was important for testis-specific expression of genes (Schäfer et al. 1990; Katzenberger et al. 2012). The CNAAATT motif appeared to be less prominent in the alternative promoters expressed when germ cells advanced to spermatocytes and was not enriched near the down-regulated promoters (Fig. 6A,H; Supplemental Fig. S5)."

\section{References}

Katzenberger RJ, Rach EA, Anderson AK, Ohler U, Wassarman DA. 2012. The Drosophila translational control element (TCE) is required for high-level transcription of many genes that are specifically expressed in testes. PLoS One 7: e45009. doi:10.1371/journal.pone.0045009

Schäfer M, Kuhn R, Bosse F, Schäfer U. 1990. A conserved element in the leader mediates post-meiotic translation as well as cytoplasmic polyadenylation of a Drosophila spermatocyte mRNA. EMBO J 9: 4519-4525.

doi: 10.1101/gad.339655.120 


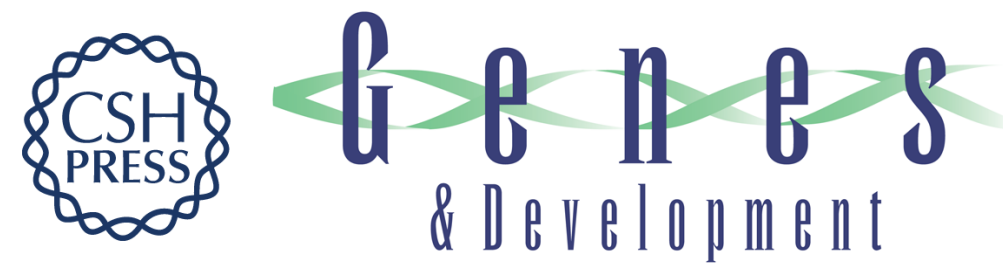

\section{Corrigendum: Developmental regulation of cell type-specific transcription by novel promoter-proximal sequence elements}

Dan Lu, Ho-Su Sin, Chenggang Lu, et al.

Genes Dev. 2020, 34:

Access the most recent version at doi:10.1101/gad.339655.120
Related Content Developmental regulation of cell type-specific transcription by novel promoter-proximal sequence elements
Dan Lu, Ho-Su Sin, Chenggang Lu, et al.
Genes Dev. May , 2020 34: 663-677

\section{License}

Email Alerting Receive free email alerts when new articles cite this article - sign up in the box at the top Service right corner of the article or click here.

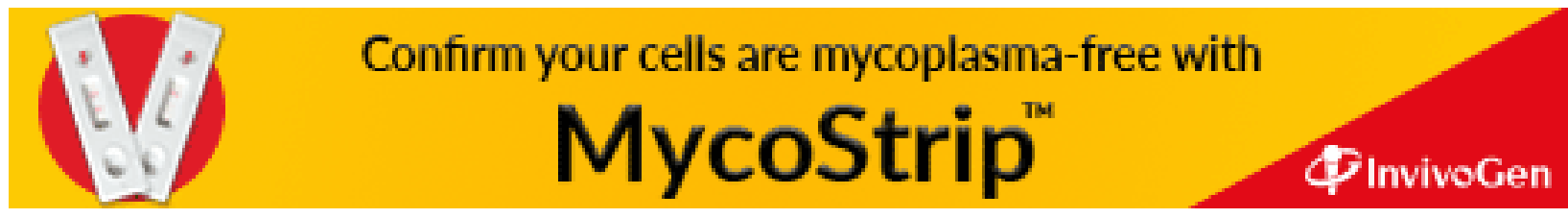

